\title{
Spatial Dimensions of Environmental Degradation in the Coastal Areas of South West
}

\author{
Joy Oluwatomi Jiboye ${ }^{1 *}$, Christopher Ogolo Ikporukpo ${ }^{2}$, Charles Olufisayo Olatubara ${ }^{2}$ \\ ${ }^{1}$ Pan African University, Institute of Life and Earth Sciences (PAULESI), University of Ibadan, Ibadan, NIGERIA \\ 2 University of Ibadan, Ibadan, NIGERIA
}

*Corresponding Author: oluwatomijoy@gmail.com

Citation: Jiboye, J. O., Ikporukpo, C. O. and Olatubara, C. O. (2019). Spatial Dimensions of Environmental Degradation in the Coastal Areas of South West. European Journal of Sustainable Development Research, 3(3), em0088. https://doi.org/10.20897/ejosdr/3973

Published: March 21, 2019

\begin{abstract}
Environmental degradation is an increasing problem in many parts of the world and the type of ecology prevalent in an area is a major factor that determines the extent to which the area should be degraded. This study examined spatial dimension of environmental degradation prevalent in the coastal areas of south west, Nigeria. It also puts into consideration the level of severity of the environmental problems and the various ecological zones in which the surveyed communities in the study area are located. Environmental degradation is the major concept in this study and the DPSIR framework was used in understanding the concept. Mixed-method approaches, involving qualitative and quantitative methodology for data collection were used. The main techniques for primary data collection were questionnaire survey. The questionnaire was administered proportionally to 1,782 respondents who are coastal dwellers that are involved in different economic activities within the coastal areas. Both descriptive (such as frequencies, percentages, charts) and inferential (One-away Analysis of Variance and Person correlation) statistics were used for data analysis as well as cartographic analysis (map). Result shows that there is a significant variation in the spatial dynamics of environmental degradation across the sampled settlements $(p<0.05)$. Flooding was ranked as the most severe environmental problem by larger percentages of respondents in strand ecological zone $(67.0 \%)$, in deltaic swamp ecological zone $(52.0 \%)$ and in mangrove ecological zone $(54 \%)$. The study concludes that flooding, water hyacinth invasion and pollution which include both sewage pollution in water bodies and open refuse dumping in drainages and along road sides was reported are the most common environmental problems reported by most of the communities, whereas flooding is the most severe environmental problem that cut across the study area. Therefore, the study recommends that, rigorous community efforts are needed to provide leadership and modalities for the management of environmental challenges such as flooding in coastal communities.
\end{abstract}

Keywords: environmental degradation, spatial dimensions, ecological zone, coastal areas and south west, Nigeria

\section{INTRODUCTION}

Throughout the history of the world, one of the greatest and persistent threats to human existence has been environmental degradation (Onumadu, et al., 2001; Oladeji, 2007). According to the United Nations (2007) environmental degradation is the deterioration of the natural environment through human activities and natural processes. 
Environmental degradation is one of the Ten Threats officially recognized by the High Level Threat Panel of the United Nations (UN, 2004). The United Nations International Strategy for Disaster Reduction (UNISDR, 2007) defines environmental degradation as "The reduction of the capacity of the environment to meet social and ecological objectives, and needs". It could also suggest the reduction in value of the environment to meet its ecological and socioeconomic needs. It includes issues such as land degradation, deforestation, desertification, loss of biodiversity, land, water and air pollution, climate change, sea level rise and ozone depletion.

Environmental degradation of varying types and degree are generally un-evenly distributed in most countries and Nigeria is not an exception. Ranging from the less devastating such as sheet erosion and mild gullies, to highly dangerous types such as loss of biodiversity, drought and loss of soil bio-physical characteristics, a typical environment in Nigeria may be occupied with one or overlapping sets of degradation consequences (Danjuma et al., 2014). Nigeria has a total coastline of about $963 \mathrm{~km}$ in a west-east stretch from Lagos to Cross River with over 20 million people living along the coastal area. Currently, the Nigeria population of about 186 million significantly put it as the most populous black nation. The population accounts for $2.3 \%$ of the world's total population, with about $2 \%$ growth rate. About $20 \%$ of Nigeria's residents also live in one of the nine coastal states which have greater number of biodiversity resources (Nigeria Biodiversity and Tropical Forestry Assessment, 2008). Because of the large number of this population that lives below poverty line, there is increase in the pressure on the coastal resources.

The biggest threat to the coastal resources in Nigeria therefore, is poverty, through land base activities (Awosika et al., 2001); as the resources remain their main cheap sources of food and income. In Nigeria, as at 1997 there were 5,081 plants species, out of which $0.40 \%$ are threatened and $8.5 \%$ endangered; 22,090 animal species $(20,000$ being insects), $0.14 \%$ of which are threatened and $0.22 \%$ endangered and 1,498 species of microorganism. Given their biological, biochemical, medicinal, sociological, and economic as well as aesthetics value, mankind must ensure that these resources are adequately protected as essential component of the natural restoration process in the coastal environment (Okebukola, 2001). The current pace of environmental change in Nigeria prompted partly by degradation continues at an alarming proportion (Weller, 2005).

The close proximity of the southern part of Nigeria to the Atlantic Ocean together with the existing wind patterns and soil classes, bestows on Southern western Nigeria diverse ecological habitats. Ecological habitats that can be found around this area include the strand vegetation, mangrove vegetation, forest and deltaic swamp (Twumasi, 2006). Different ecosystems experience different types of degradation depending on the prevailing climatic conditions. The type of ecology prevalent in an area will be a major factor that determines the extent to which the area could be degraded.

Previous studies on the spatial dynamics of environmental degradation have been largely on how a specific type of degradation influences a particular sphere of activity or people. For instance, Xue (2006) examines the spatialtemporal dynamic change of land degradation in china. He observed that seven major types of land degradation processes exist in the areas he surveyed. They include sandy desertification, rocky desertification, secondary salinification, non-agricultural land occupation, deforestation, natural grassland degradation and wetlands shrinking. The paper comprehensively explored the characteristics of these land degradation processes and revealed the status and trend of the holistic land resource degradation in China. Igben (2012) studies the impact of temporal dynamics of environmental degradation on the occupation of the labour force in Delta state Nigeria. The study revealed that there is a significant temporal change in the occupations of the labour force. However, issues of spatial dynamics in the area of coastal environment and degradation has been ignored. This study is therefore designed to fill this gap. The aim of this study is to analyse the spatial dimensions of environmental degradation in the coastal areas of south west Nigeria and to achieve this aim, the study examined the spatial dimensions of environmental degradation over space and environmental degradation across ecological zones

\section{STUDY AREA}

The study area (southwestern coastal area of Nigeria) stretches from Nigeria/Benin Republic border and terminates at the Ondo-Edo border (part of Niger-Delta Region). It lies approximately between latitude $6^{\circ} 10^{\prime}$ to $6^{\circ} 50^{\prime} \mathrm{N}$ and longitude $2^{\circ} 45^{\prime}$ to $6^{\circ} 09^{\prime} \mathrm{E}$ (see Figure 1). The study area cuts across three states (Lagos, Ogun and Ondo states) of the eight coastal states of Nigeria. It is about $324 \mathrm{~km}$ long, which is $33.6 \%$ of the nation's coastline of $963 \mathrm{~km}$ (Eze et al., 2016). This is presented in Table 1. 
European Journal of Sustainable Development Research, 3(3), em0088

Table 1. Coastlines of Nigeria by States

\begin{tabular}{lcc}
\hline State & Length of coastline in $\mathbf{~ k m}$ & \% of total coastline \\
\hline Lagos & 171 & 17.76 \\
\hline Ogun & 69 & 7.17 \\
\hline Ondo & 84 & 8.72 \\
\hline Delta & 117 & 12.15 \\
\hline Bayelsa & 186 & 19.31 \\
\hline Rivers & 111 & 11.53 \\
\hline Akwalbom & 96 & 9.97 \\
\hline Cross rivers & 129 & 13.40 \\
\hline Total & 963 & 100 \\
\hline
\end{tabular}

Source: Eze et al. (2016)

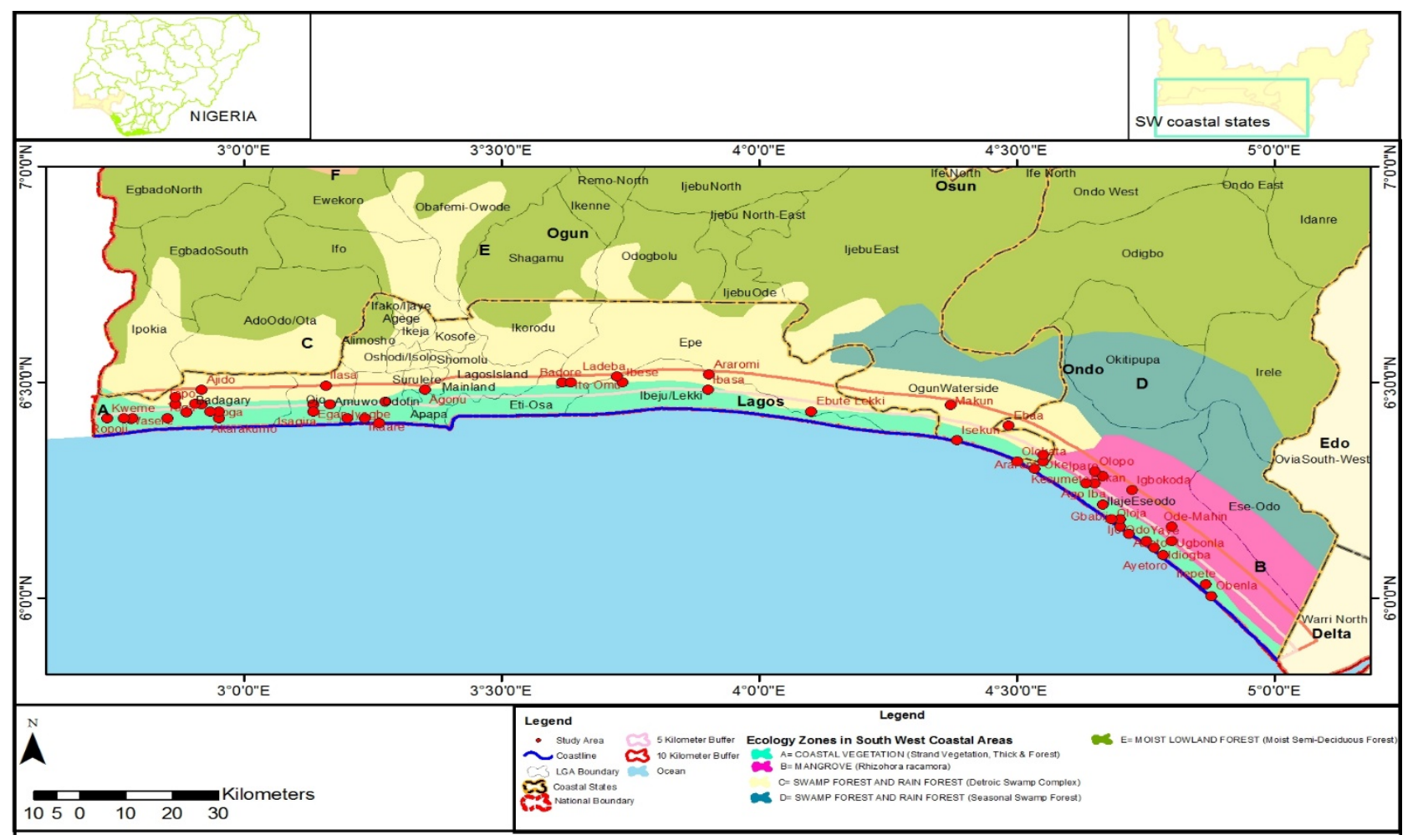

Figure 1. South West showing the Study Area

Source: Author's fieldwork (2018)

\section{CONCEPTUAL FRAMEWORK}

The United Nations International Strategy for Disaster Reduction characterizes environmental degradation as the lessening of the limit of the earth to meet social and environmental destinations, and needs (UNISDR, 2007). According to Kukreja (2015) environmental degradation is the disintegration of the earth or deterioration of the environment through consumption of assets, for example, air, water and soil; the destruction of environments and the eradication of wildlife. It is characterized as any change or aggravation to nature's turf seen to be pernicious or undesirable. Ecological impact or degradation is created by the consolidation of an effectively substantial and expanding human populace, constantly expanding monetary development or per capita fortune and the application of asset exhausting and polluting technology. It occurs when earth's natural resources are depleted and environment is compromised in the form of extinction of species, pollution in air, water and soil, and rapid growth in population. Environmental degradation is also the deterioration in environmental quality from ambient concentrations of pollutants and other activities and processes such as improper land use and natural disasters, (OECD 2001).

In general, the environment provides all life support systems of every human society. These life support systems are built and sustained by the natural resources found in air, land and water. These resources include fresh/safe water, fish, arable land, plants, animals, mineral resources, air, among others. These resources often come in variable quantity and quality. Humans therefore exploit these resources for survival and sustenance. The misuse or over-use of these resources affects their quality and/or quantity in comparison with their pristine availability in 


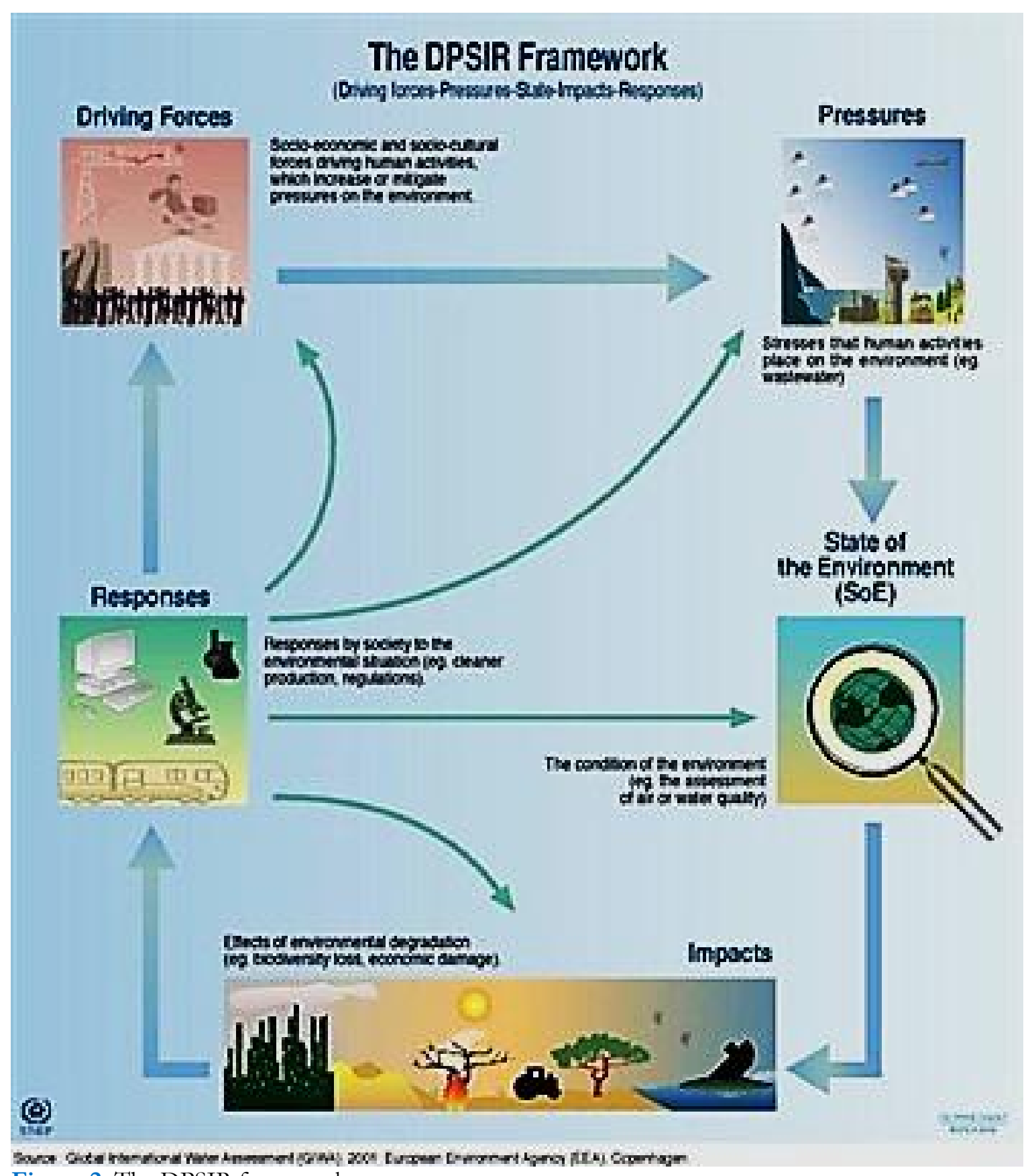

Figure 2. The DPSIR framework

Source: Global International Water Assessment (GIWA), 2001

the environment. Therefore, the issue of environmental degradation comes into play when these resources diminish in quantity or quality, or both. According to Jimoh (2006), environmental degradation refers to: The downward trend in the environmental resources such that their level of use in the human societies equally decreases at an increasing rate.

The European Environmental Agency (EEA), within the legal basis of the European Union Environmental Policy Acts 95, 174, 175 and 176 of the consolidated version of the Treaty on European Union and under the auspices of the European Commission, in their effort to introduce environmental issues in their developmental agenda, further improved the existing assessment frameworks into a five indicator framework (which includes PSR and DSR as special cases) dubbed as the "DPSIR assessment framework" (Jesinghaus, 1998; Pierce, 1998; EEA, 1999) (see Figure 2).

Each indicator conveys its own distinctive meaning and application. The framework is seen as giving a structure within which to present the indicators needed to enable feedback to policy makers on environmental quality and the resulting impact of the political choices made, or to be made in the future (Kristensen, 2004). "Driving forces" are social processes that cause either the increase or mitigation of pressures on the environment. Examples of such social processes are population growth, migration, poverty, level of production, human behaviours and attitudes 
and consumption pattern (Rigby et al., 2000). "Pressures" are represented by direct human activities on the environment, such as exploitation and excessive consumption of natural resources, beyond its carrying capacity, carbon dioxide emission into the environment, the use of fluorocarbons, use of mercury, lead, arsenic and cyanide in the purification and smelting of gold ores and the use of lead as an ingredient of gasoline (Rigby et al., 2000).

The "state" relates to the spatio-temporal changes to the environment that include rising global temperatures, ozone layer depletion, environmental degradation, soil erosion, soil compaction, desertification, deforestation, global warming, acidification and eutrophication. The "impacts" are the consequences of observed changes on the environment that include fall in agricultural production, percentage of children suffering from lead induced problems, food insecurity, malnutrition, mortality due to noise-induced heart attacks and number of people starving due to climate-change induced crop losses. The "responses" are what the society perceives to be done to realize a better environment and that include introduction of energy taxes, polluter pays principles, environmental conservation, environmental movement, environmental awareness programmes, environmental capacity building and mitigation measures (Pierce, 1998). The DPSIR assessment framework considers all the important indicators of environmental degradation assessment, hence its adoption in this study.

\section{LITERATURE REVIEW}

The concepts of space, spatial distribution, spatial interaction, spatial behaviour, location and inter-linkages are used for the understanding of the causes and consequences of environmental challenges. Environmental problems in Nigeria are not restricted to any particular sector of the country. Like the harmattan wildfire, it acts across all regions of the country-rural and urban (Okosodo and Omonzejie, 2004). Also, it cuts across the different geopolitical zones of the country. Environmental scholars in the country have also classified the problems according to vegetal, climatic, coastal, Niger-Delta and oil producing areas (Uche, 1995; Okosondo and Omonzejie, 2004; Dimuna and Dimuna, 2007; Ademiluyi and Solanke, 2004; and Ofomata and Phil-Eze, 2007). The different ecological zones of Nigeria are associated with peculiar human and economic practices and their attendant ecological and environmental problems (Okosodo and Omonzejie, 2004).

Nigeria is not spared of her own share of natural disasters (Fatubarin, 2009). The most common natural disasters in the country are desertification, landslides, flood, and erosion. These problems are distributed across the country based mainly on the prevailing geological, vegetal, hydrological or climatic condition. For instance, desert encroachment is a major problem in the Sahel vegetation region of Nigeria. It is widespread in areas like Sokoto, Maiduguri, Birni-Kebbi and Damaturu. The problem is equally noticeable in the North Eastern part of the country. Associated problems of dr+ought and vegetation loss are obvious in Kebbi, Sokoto, Kastina, Kano, Jigawa, Yobe and Borno States. Also, coastal erosion is peculiar to some states in the southern parts of the country. It is common in states like Lagos, Delta, Bayelsa, Akwa Ibom, Rivers and Cross Rivers. Likewise, gullies are prominent in Anambra, Imo, Adamawa, Ogun, Akwa-Ibom, Cross Rivers, Benue, Abia, Bayelsa, and Ekiti State. Furthermore, the problem of flooding is prevalent along the banks of Rivers Gongola, Taraba, Ogunpa, Sontau and Donga. Other areas that are affected by flooding are the South East coastal plains, the Cross Rivers basin, the Eastern Scarp lands, and the Niger Delta. Likewise, urban flooding is ubiquitous in cities like Lagos, Ibadan, Port Harcourt, Calabar, Yenagoa, Ibadan, Asaba and Benin City (Uche, 1995; Siyanbade, 2006; Petters, 1995; Ofomata and Phil-Eze, 2007; and Jimoh, 2000).

The urban centres of the country are also characterized by unsightly city-scape pressure on natural habitats, urban aesthetics inadequate housing, collapsed buildings and poor environmental condition. Other problems that are peculiar to the urban centres are overcrowding, crimes, insecurity, outbreak of diseases, solid wastes, poor sanitation and hygiene, water scarcity, traffic congestion, and pollution of all types. Similarly, the rural areas are faced with the challenges of poor facilities for waste collection and disposal, dangerous agricultural practices, loss of farmland, soil erosion, inadequate sanitation, as well as insufficient amenities and social infrastructure. Moreover, the oil producing areas like Akwa Ibom, Cross River, Rivers, Abia, Bayelsa, Ondo, Delta, Edo and Anambra are characterized by the problems of oil spillage, siltation of water bodies, over fishing, land degradation, biodiversity loss, increased watershed instability, as well as extinction of rare species of flora and fauna. For the people in the Niger Delta, the major issues in contention today are environmental pollution and resource control (Dimuna and Dimuna, 2007). Other problems in the Niger Delta region are land degradation, oil spillage, flooding, erosion and reduction in soil productivity. Similarly, loss of soil fertility, bad land and dereliction are the major challenges in the mining regions of Jos, Enugu, Itakpe, Nkalagun and Ijero. 
Table 2. Population Size from Each Sampled Settlement

\begin{tabular}{|c|c|c|c|c|}
\hline $\mathrm{S} / \mathrm{N}$ & Settlement & Population & Population in $\%$ of total & Sampled population size \\
\hline 1. & Abalala & 1,189 & 0.8 & 14 \\
\hline 2. & Aboto & 5,017 & 3.3 & 59 \\
\hline 3. & Ago Iba & 2,112 & 1.4 & 25 \\
\hline 4. & Agonu & 290 & 0.2 & 4 \\
\hline 5. & Ajido & 3,357 & 2.2 & 39 \\
\hline 6. & Akarakumo & 575 & 0.4 & 7 \\
\hline 7. & Aradagun & 399 & 0.3 & 5 \\
\hline 8. & Araromi & 5,505 & 3.7 & 66 \\
\hline 9. & Araromi Obu & 592 & 0.4 & 7 \\
\hline 10. & Araromi Oke & 565 & 0.4 & 7 \\
\hline 11. & Ayetoro & 4,994 & 3.3 & 59 \\
\hline 12. & Badagry & 23,959 & 16.0 & 286 \\
\hline 13. & Badore & 501 & 0.3 & 5 \\
\hline 14. & Ebaa & 2,942 & 2.0 & 36 \\
\hline 15. & Ebute Lekki & 230 & 0.2 & 4 \\
\hline 16. & Egan & 279 & 0.2 & 4 \\
\hline 17. & Etikan & 1,474 & 1.0 & 18 \\
\hline 18. & Ganyingbo & 153 & 0.1 & 2 \\
\hline 19. & Gbabijo & 4,168 & 2.8 & 50 \\
\hline 20. & Ibasa & 376 & 0.3 & 5 \\
\hline 21. & Ibereko & 11,564 & 7.7 & 138 \\
\hline 22. & Ibese & 2,069 & 1.4 & 25 \\
\hline 23. & Idiogba & 5,544 & 3.7 & 66 \\
\hline 24. & Igbede & 3,621 & 2.4 & 43 \\
\hline 25. & Igbogbele & 712 & 0.5 & 9 \\
\hline 26. & Igbokoda & 4,918 & 3.3 & 59 \\
\hline 27. & Ijo Odo & 2,862 & 1.9 & 34 \\
\hline 28. & Ikare & 591 & 0.4 & 7 \\
\hline 29. & Ilasa & 1,808 & 1.2 & 21 \\
\hline 30. & Ilepete & 13,561 & 9.0 & 161 \\
\hline 31. & Ipare & 1,507 & 1.0 & 18 \\
\hline 32. & Isagira & 693 & 0.5 & 9 \\
\hline 33. & Isekun & 317 & 0.2 & 4 \\
\hline 34. & Ito Omu & 148 & 0.1 & 2 \\
\hline 35. & Itoga & 430 & 0.3 & 5 \\
\hline 36. & Iyafin Isalu & 503 & 0.3 & 5 \\
\hline 37. & Iyagbe & 781 & 0.5 & 9 \\
\hline 38. & Kesumetta & 322 & 0.2 & 4 \\
\hline 39. & Kweme & 717 & 0.5 & 9 \\
\hline 40. & Ladeba & 242 & 0.2 & 4 \\
\hline 41. & Makun & 1,658 & 1.1 & 20 \\
\hline 42. & Obe Nla & 4,918 & 3.3 & 59 \\
\hline 43. & Ode-Mahin & 5,429 & 3.6 & 64 \\
\hline 44. & Okun Ibese & 962 & 0.6 & 11 \\
\hline 45. & Oloja & 1,029 & 0.7 & 13 \\
\hline 46. & Olokata & 1,254 & 0.8 & 14 \\
\hline 47. & Olopo & 686 & 0.5 & 9 \\
\hline 48. & Olotu/Eruna & 1,400 & 0.9 & 16 \\
\hline 49. & Olute & 6,861 & 4.6 & 82 \\
\hline 50. & Panko & 131 & 0.1 & 2 \\
\hline 51. & Ropoji & 302 & 0.2 & 4 \\
\hline 52. & Topo & 3,750 & 2.5 & 45 \\
\hline 53. & Toga & 3,738 & 2.5 & 45 \\
\hline 54. & Ugbonla & 4,893 & 3.3 & 59 \\
\hline 55. & Wasere & 355 & 0.2 & 4 \\
\hline \multirow[t]{2}{*}{56.} & Yaye & 1,109 & 0.7 & 13 \\
\hline & & 150,062 & 100.0 & 1789 \\
\hline
\end{tabular}

\section{MATERIALS AND METHODS}

The primary data used for this research was obtained from questionnaire surveys. A total of fifty-six (56) settlements were sampled from west to east along the coastline and between zero and ten kilometres away from the coast putting into consideration the ecological zones. The numbers of coastal settlements were acquired from a 2015 satellite imagery produced by Google Earth (with a resolution of about $15 \mathrm{~m}$ per pixel. This base imagery 
is $30 \mathrm{~m}$ multispectral Landsat which is pansharpened with the $15 \mathrm{~m}$ [panchromatic] Landsat imagery). Also, the names of the settlements were obtained from existing maps of the study area and through ground trothing, the names and sites of these settlements were obtained and indexed appropriately. The coastal boundary shown on the imagery was digitized and over-laid with the existing administrative and ecological maps of the concerned states with the aid of ArcGIS. Also, the population data of all the localities of each state within the study area was obtained from the National Population Commission office of the respective states. The total population of this study is One hundred and fifty thousand, sixty two people $(150,062)$ (NPC, 2006). From this, a sample size of seven hundred and eighty-two $(1,782)$ was determined using Yamane (1967) sampling formula.

$\mathrm{n}=$ sample size

$$
n=\frac{N}{1+N(e)^{2}}
$$

$\mathrm{N}=$ Population size

$\mathrm{e}=$ margin of error (e) which is fixed at $2.35 \%$

Table 2 shows the selected communities across the study area, their population size and the number of questionnaires administered per settlement. It is also important to note that most of these sampled settlements are rural in nature. The respondents include both male and female of different socio-economic status. The semistructured questionnaire reflects the perceived type(s) of environmental degradation present in the settlements. It also addresses the order of severity of the perceived degradation type. Both descriptive (such as frequencies, percentages, charts and maps) and inferential statistics (Analysis of Variance and Person correlation) were used to analyse the data at $\mathrm{p}<$ or $=0.5$ level of significance.

\section{RESULTS AND FINDINGS}

\section{Environmental Degradation across Locations}

There are various types of environmental degradation (from the left edge of Badagry to the Ilaje region) in the study area. Perception of respondents of the environmental degradation varies from one location to another as shown in Figure 3. The environmental degradations in the surveyed settlements are present in a mixed form. Respondents in Abala stated that coastal erosion, invasion of the area by water hyacinth, in addition to the problem of flooding are some of the area's environmental degradations. Aboto and Ago Iba respondents indicated coastal erosion, flooding pollution and sand dredging. Agonu, Igbogble, Ladeba and Makun experience flooding, water hyacinth invasion on their water bodies and also soil infertility. This mixed form of environmental degradations presents itself in most of the surveyed settlements as shown in Table 3.

Table 3. Most Severe Environmental Degradation across Locations

\begin{tabular}{|c|c|c|c|}
\hline $\begin{array}{l}\text { Most severe environmental } \\
\text { degradation }\end{array}$ & Settlement & $\begin{array}{l}\text { Frequency (No. } \\
\text { of settlements) }\end{array}$ & $\begin{array}{c}\text { No of settlements } \\
\text { in percentage of } \\
\text { total }\end{array}$ \\
\hline Coastal erosion & Ito omu, Iyagbe & 2 & 3.6 \\
\hline Flooding & $\begin{array}{l}\text { Abalala, Aboto, Ago Iba, Agonu, Aradagun, Araromi, } \\
\text { Araromi Obu, Ayetoro, Badagry Town, Ebaa, Ebute } \\
\text { Lekki, Egan, Etikan, Gbabijo, Ibereko, Idiogba, } \\
\text { Igbede, Igbogbele, Igbokoda, Ijo Odo, Ilasa, Ilepete, } \\
\text { Ipare, Isagira, Isekun, Itoga, IyafinIsalu, Obenla, } \\
\text { Ode- Mahin, Oloja, Olokata, Olotu/Eruna, Olute, } \\
\text { Panko, Ropoji, Toga, Topo, Ugbonla, Wasere, Yaye }\end{array}$ & 40 & 71.4 \\
\hline Water hyacinth invasion & Kesumetta, Makun, Okun Ibese & 3 & 5.4 \\
\hline Coastal erosion and flooding & Ibasa, Ibese & 2 & 3.6 \\
\hline $\begin{array}{l}\text { Coastal erosion, flooding, water } \\
\text { hyacinths }\end{array}$ & Araromi oke, Badore & 2 & 3.6 \\
\hline $\begin{array}{l}\text { Coastal, flooding, water hyacinth, soil } \\
\text { infertility, sand mining }\end{array}$ & Ikaare & 1 & 1.8 \\
\hline Flooding and water hyacinth & Ajido & 1 & 1.8 \\
\hline Flooding and pollution & Akarakumo & 1 & 1.8 \\
\hline Flooding and soil infertility & Ladeba & 1 & 1.8 \\
\hline $\begin{array}{l}\text { Flooding, water hyacinth, pollution, soil } \\
\text { infertility, others }\end{array}$ & Olopo & 1 & 1.8 \\
\hline Water hyacinth and soil infertility & Ganyingbo & 1 & 1.8 \\
\hline \multirow[t]{2}{*}{ Pollution, soil infertility } & Kweme & 1 & 1.8 \\
\hline & & 56 & 100.0 \\
\hline
\end{tabular}




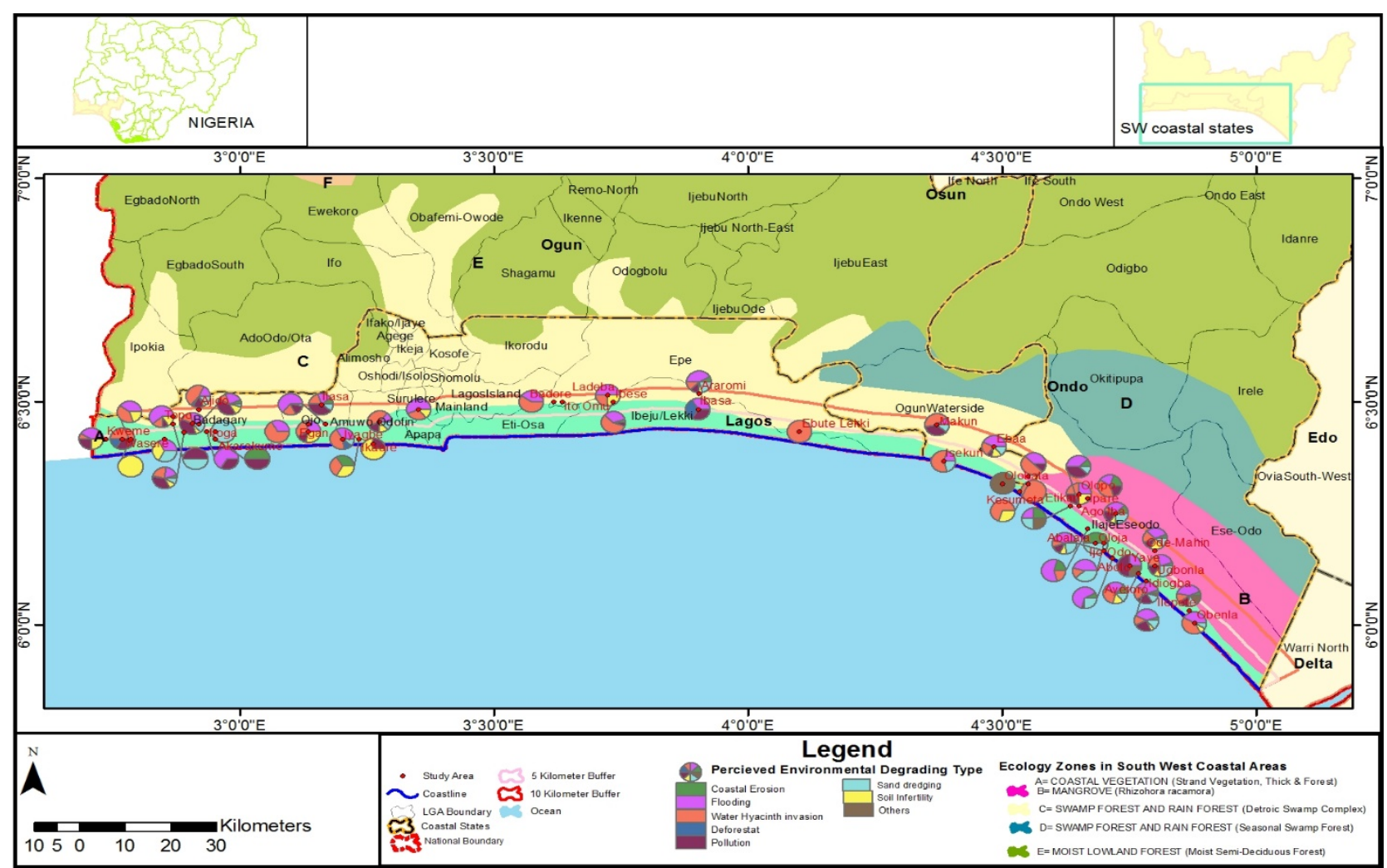

Figure 3. South west showing the environmental degradation in the surveyed settlements Source: Author's fieldwork (2018)

Flooding and water hyacinth invasion are the most common environmental degradations in the study area. Flooding was a consistent problem being mentioned by the respondents in most of the surveyed settlements. Only twenty per cent $(20 \%)$ of the surveyed settlements had other environmental degradations which does not include flooding. Also, water hyacinth was indicated as an environmental issue in seventy-five per cent $(75 \%)$ of the settlements. It is also a common problem being faced in most of the settlements. Coastal erosion was indicated in forty-one per cent (41\%) of the surveyed communities, while deforestation/mangrove degradation was indicated in eleven per cent of the surveyed communities. These eleven percent communities are evenly distributed across the study area. Pollution which include both sewage pollution in water bodies, and open refuse dumping in drainages and along road sides was reported as a problem in sixty-three per cent $(63 \%)$ of the settlements. These settlements are also evenly spread in the study area. Soil in fertility was reported in the western side of the study area as compared to the eastern territory. Sand dredging was also identified as a contributing factor in the eastern territory of the study area (Figure 3). From these brief analyses, it can be seen that flooding, water hyacinth and pollution are the most common environmental degradation being encountered in the entire study area and they occur evenly, while soil infertility and sand mining occur in specific areas. It is important to note that most common environmental degradation is not the most severe environmental challenge being faced by the communities because the severity of the environmental degradation differs per settlement.

\section{Most Severe Environmental Degradation across Locations}

Perception of respondents of the most severe environmental degradations varies from one location to another as it can be seen from Figure 4. A larger percentage of about sixty two per cent $(62.4 \%)$ stated that flooding is the most severe environmental degradation in their locality. About ten per cent $(10 \%)$ each indicated coastal flooding and pollution respectively as the most severe problem their environment is being faced with. This shows that flooding remains the most severe issue the coastal inhabitants experience in their localities. This also buttresses the point raised in the previous section that the most common environmental degradation may not be the most severe. Table 3 also shows a further analysis on the number of settlements the major environmental degradations affects. Flooding was indicated as the most severe environmental problem in seventy-one per cent $(71 \%)$ of the surveyed communities. About five per cent $(5 \%)$ of the settlements face water hyacinth as their major environmental degradation. Thus it can be affirmed that flooding remains the major and most severe environmental degradation that the various settlements encounter. 


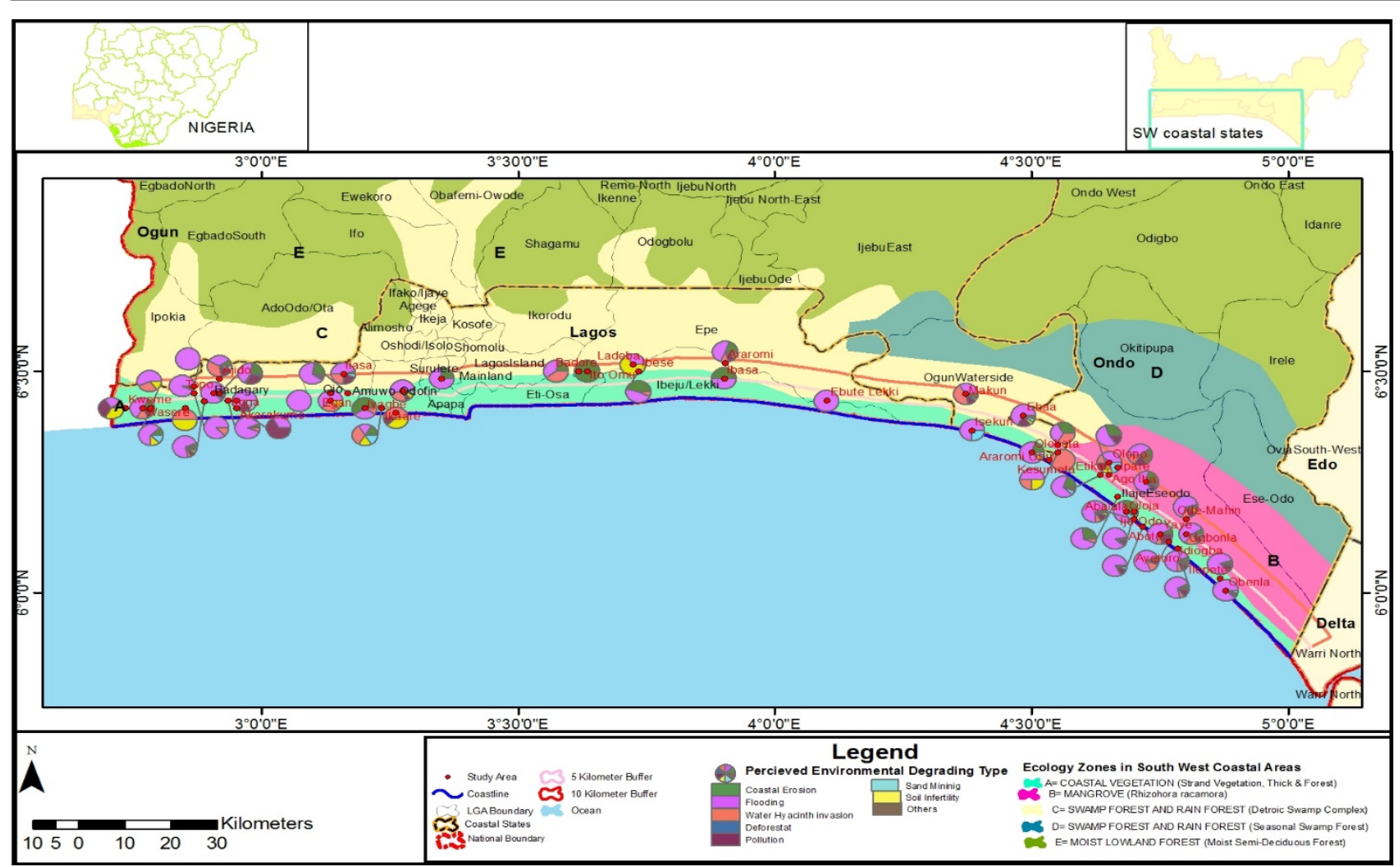

Figure 4. South west showing the most severe environmental degradation in the surveyed settlements Source: Author's fieldwork (2018)

\section{Ranking of Environmental Degradations in Order of Severity}

Analysis from Table 4, shows that flooding was also ranked highest when the respondents were asked to rank the environmental degradations facing their locality in order of severity. About sixty two per cent $(62 \%)$ of the respondents ranked flooding on rank one. On rank two, thirty six per cent (36\%) opined that flooding is the most severe environmental degradation. Thus it can be said that the most severe environmental degradation facing the coastal southwest coastal area is flooding, followed by coastal erosion and then water hyacinth invasion. This reality highlights the need for more proactive efforts towards tackling flooding in the study area. Thus this finding supports the view of Akinwale (2011) who asserted that flooding is the major problem facing Nigeria coastal areas.

Table 4. Rank of Severity of Environmental degradations

\begin{tabular}{lcccc}
\hline $\begin{array}{l}\text { Rank of severity of environmental } \\
\text { degradations }\end{array}$ & $\begin{array}{c}\text { Rank 1 } \\
\text { (Highest severity) }\end{array}$ & $\begin{array}{c}\text { Rank 2 } \\
\text { (Higher Severity) }\end{array}$ & $\begin{array}{c}\text { Rank 3 } \\
\text { (Severe) }\end{array}$ & $\begin{array}{c}\text { Rank 4 } \\
\text { (Not severe) }\end{array}$ \\
\hline Coastal erosion & 10.3 & 25.7 & 27.0 & - \\
\hline Flooding & 62.4 & 36.0 & 5.6 & 20.0 \\
\hline Water hyacinth invasion & 9.0 & 16.4 & 33.3 & 20.0 \\
\hline Deforestation/ Mangrove degradation & .2 & - & 4.0 & 60.0 \\
\hline Pollution & 9.7 & 12.4 & 18.3 & - \\
\hline Soil infertility & 3.5 & 1.4 & .7 & - \\
\hline Sand mining & 2.6 & 5.9 & 10.3 & - \\
\hline Others & 2.3 & 2.2 & .8 & - \\
\hline Total & 100.0 & 100.0 & 100.0 & 100.0 \\
\hline
\end{tabular}

Source: Author's Analysis (2018)

\section{Variation in Environmental Degradation across Different Locations}

The Analysis of Variance (ANOVA) test result as shown in Table 5, ascertaining if there is any significant variation in the spatial dynamics of environmental degradation showed that there is, with an F: 11.211; $\mathrm{p}<0.05$. This indicates that the forms of environmental degradation that have taken place in the study area are not the same across the areas sampled and the variation is statistically significant. Thus the hypothesis which states that there is a significant variation in environmental degradation is accepted.

Table 5. Variation in Environmental Degradation across Different Locations

\begin{tabular}{lccccc}
\hline & Sum of Squares & df & Mean Square & F & Sig. \\
\hline Between Groups & .698 & 2 & \multirow{2}{*}{11.211} & \multirow{2}{*}{.000} \\
\cline { 1 - 4 } Within Groups & 55.414 & 1779 & .031 & & \\
\cline { 1 - 4 } Total & 56.112 & 1781 & & &
\end{tabular}

Source: Author's Analysis (2018) 


\section{Environmental Degradation across Ecological Zones}

Figure 5 shows that the perception of respondents on the particular environmental issue in their ecological zones varies. In the strand, thick and forest vegetation, the environmental degradations in the various localities include flooding (35.8\%), water hyacinth invasion $(21.1 \%)$, coastal erosion (16.6\%), pollution $(10.2 \%)$, Sand mining $(7.6 \%)$, and so on. The perception at the deltaic vegetation did not have the same pattern as we have it in the strand, thick and forest vegetation. Here, flooding come first with about thirty two per cent $(32.1 \%)$, followed by pollution with about twenty three per cent $(22.9 \%)$, then water hyacinth invasion $(19.9 \%)$, coastal erosion (10.6\%), sand mining $(9.2 \%)$, and so on. A greater number of respondents of about thirty eight per cent $(37.9 \%)$ within the mangrove vegetation indicated sand mining, thirty one per cent (31.3\%) indicated flooding, eleven per cent $(11.1 \%)$ water hyacinth, and seven per cent $(7.0 \%)$ coastal erosion as the problem facing their environment.

Comparing the major environmental degradation across the ecological zones, it can be seen that the strand, thick and forest ecological zone experience more of flooding, followed by water hyacinth, pollution and sand mining. In the deltaic swamp ecological zone there was more of flooding followed by pollution, water hyacinth and then coastal erosion. What obtains in the mangrove ecological zone was different as sand mining was indicated to the dominant, followed by flooding and then pollution. This does not indicate the total absence of flooding in the mangrove ecological zone, but just in a reduced degree.

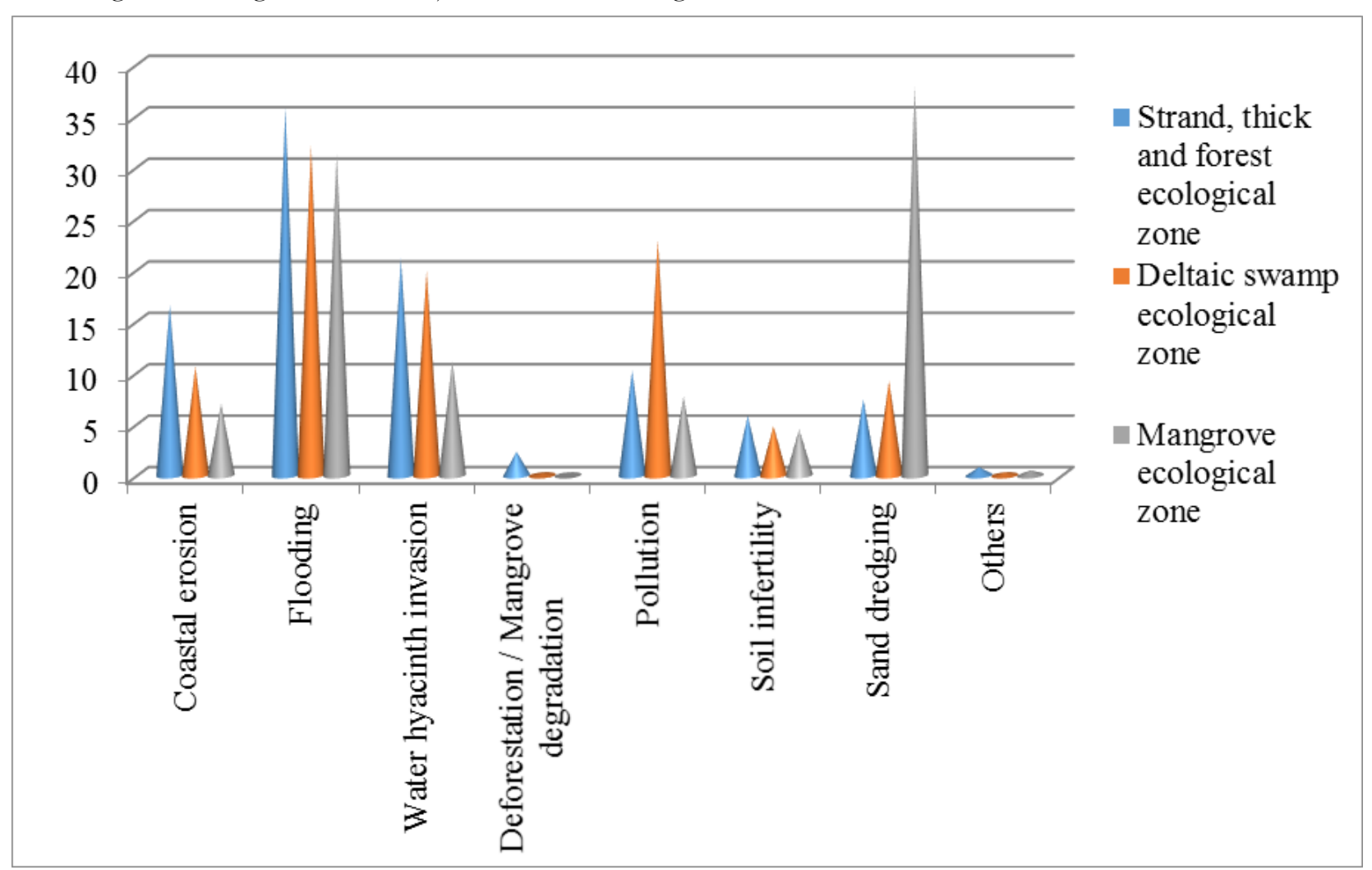

Figure 5. Environmental degradation across ecological zones

Source: Author's Analysis (2018)

\section{Most Severe Environmental Degradation across Ecological Zones}

A greater percentage of respondents in the three ecological zones indicated flooding as the most severe environmental degradation. In clear terms, about sixty seven percent (66.8\%), fifty two percent $(52.2 \%)$ and fifty four percent $(53.9 \%)$ in the strand, deltaic and mangrove ecological zones respectively indicated flooding as the most severe environmental degradations facing their ecological zone.environmental degradationenvironmental degradation. These is shown in Table 6. Water hyacinth was indicated to be more severe in the mangrove ecological zone while coastal erosion was presented as most severe in the deltaic swamp ecological zone. Deforestation and mangrove degradation was not a severe problem in any of the zones. From this analysis, the most obvious explanation is that flooding is the most severe environmental degradation in the three ecological zones, while issues such as deforestation and mangrove degradation were not common. 
European Journal of Sustainable Development Research, 3(3), em0088

Table 6. Most Severe Environmental degradation Across Ecological Zones

\begin{tabular}{lccc}
\hline Most severe environmental degradation & Strand, thick and forest & Deltaic Swamp & Mangrove \\
\hline Coastal erosion & 8.4 & 16.7 & 11.0 \\
\hline Flooding & 66.8 & 52.2 & 53.9 \\
\hline Water hyacinth invasion & 8.7 & 7.7 & 13.1 \\
\hline Deforestation/Mangrove degradation & .2 & .3 & - \\
\hline Pollution & 7.7 & 16.1 & 10.5 \\
\hline Soil infertility & 3.7 & 2.3 & 4.2 \\
\hline Sand mining & 2.8 & 1.7 & 3.1 \\
\hline Others & 1.7 & 3.0 & 4.2 \\
\hline Total & 100.0 & 100.0 & 100.0 \\
\hline Source
\end{tabular}

Source: Author's Analysis (2018)

\section{Rank of Severity of Environmental Degradations across Ecological Zones}

The environmental degradation with the highest severity across the three ecological zones is flooding, as it can be seen from Table 7. In the strand, thick and forest vegetation, flooding was ranked as the most severe environmental degradation by about sixty seven per cent $(67 \%)$ of the respondents. This is also the case in the deltaic and mangrove vegetation as about fifty two per cent $(52 \%)$ and fifty four per cent $(54 \%)$ of the respondents indicated flood as the most severe environmental degradation they face respectively. Water hyacinth is more severe in mangrove ecological zone than it is in the strand, thick and forest and deltaic ecological zones. The severity of coastal erosion in the deltaic swamp ecological zone was higher than it is in the other two ecological zones.Mangrove degradation and sand mining were indicated as more severe in the mangrove ecological zone. In addition, other environmental issues e.g. oil spillage, was ranked as more severe in the mangrove than in the other zones.

Table 7. Rank of Severity of Environmental degradations in the Various Ecological Zones

\begin{tabular}{|c|c|c|c|c|c|c|c|c|c|c|}
\hline \multirow[t]{3}{*}{ Variables } & \multicolumn{4}{|c|}{ Strand, thick and forest } & \multicolumn{3}{|c|}{ Deltaic Swamp } & \multicolumn{3}{|c|}{ Mangrove } \\
\hline & Rank 1 & Rank 2 & Rank 3 & Rank 4 & Rank 1 & Rank 2 & Rank 3 & Rank 1 & Rank 2 & Rank 3 \\
\hline & Most Severe & Severe & Less Severe & Not severe & Most Severe & Severe & Less Severe & Most Severe & Severe & Less Severe \\
\hline $\begin{array}{l}\text { Coastal } \\
\text { Erosion }\end{array}$ & 8.4 & 26.3 & 23.3 & - & 16.7 & 21.6 & 33.3 & 11.0 & 28.4 & 66.7 \\
\hline Flooding & 66.8 & 33.5 & 3.3 & - & 52.2 & 39.7 & 12.1 & 53.9 & 44.5 & - \\
\hline $\begin{array}{l}\text { Water } \\
\text { hyacinth } \\
\text { invasion }\end{array}$ & 8.7 & 19.2 & 37.8 & 20.0 & 7.7 & 12.6 & 21.2 & 13.1 & 5.4 & 33.3 \\
\hline $\begin{array}{l}\text { Deforestation/ } \\
\text { Mangrove } \\
\text { degradation }\end{array}$ & .2 & - & 5.6 & 20.0 & .3 & - & - & 10.5 & 6.8 & - \\
\hline Pollution & 7.7 & 11.4 & 15.6 & 60.0 & 16.1 & 19.8 & 27.3 & 4.2 & - & - \\
\hline Soil infertility & 3.7 & 1.1 & 1.1 & - & 3.0 & - & - & 3.1 & 8.1 & - \\
\hline Sand mining & 2.8 & 6.4 & 12.2 & - & 2.3 & 3.6 & - & 4.2 & 6.8 & - \\
\hline Others & 1.7 & 2.1 & 1.1 & - & 1.7 & 2.7 & 6.1 & 11.0 & 28.4 & 66.7 \\
\hline Total & 100.0 & 100.0 & 100.0 & 100.0 & 100.0 & 100.0 & 100.0 & 100.0 & 100.0 & 100.0 \\
\hline
\end{tabular}

Source: Author's Analysis (2018)

\section{Variation in Environmental Degradation across the various Ecological Zones.}

The ANOVA test results ascertaining if there is any significant variation in environmental degradation in the different ecological zones showed that there was, with an F: 18.755; $\mathrm{p}<0.05$ in the strand, thick and forest ecological zone, F: $0.981 ; \mathrm{p}<0.05$ in the deltaic ecological zone, and F: $0.189 ; \mathrm{p}<0.05$ in the mangrove ecological zone. This indicates that the environmental degradation that has taken place in the study area is not the same across the areas sampled and the variation is statistically significant (Table 8). Thus, the hypothesis which states that there is a significant variation in environmental degradation over time across different ecological zones is accepted.

Table 8. Variation in Environmental Degradation Across Different Ecological Zones

\begin{tabular}{|c|c|c|c|c|c|c|}
\hline & & Sum of Squares & df & Mean Square & $\mathbf{F}$ & Sig. \\
\hline \multirow[t]{3}{*}{ Strand thick and forest ecological zone } & Between Groups & 3.114 & 4 & .779 & \multirow{3}{*}{18.755} & \multirow{3}{*}{0.000} \\
\hline & Within Groups & 50.309 & 1212 & .042 & & \\
\hline & Total & 53.423 & 1216 & & & \\
\hline \multirow[t]{3}{*}{ Deltaic swamp ecological zone } & Between Groups & .014 & 4 & .003 & \multirow{3}{*}{0.981} & \multirow{3}{*}{.418} \\
\hline & Within Groups & 1.979 & 560 & .004 & & \\
\hline & Total & 1.993 & 564 & & & \\
\hline \multirow[t]{3}{*}{ Mangrove ecological zone } & Between Groups & .075 & 3 & .025 & \multirow{3}{*}{0.189} & \multirow{3}{*}{.904} \\
\hline & Within Groups & 17.706 & 133 & .133 & & \\
\hline & Total & 17.781 & 136 & & & \\
\hline
\end{tabular}

Source: Author's Analysis (2018)

(C) 2019 by Author/s 


\section{CONCLUSION AND RECOMMENDATIONS}

Environmental degradation in the study area varies across the coastal areas. Flooding was dominant in Aboto, Ayetoro, Idiogba, Ijo odo, Itoga and Toga while water hyacinth was more severe in Abalala, Agonu, Ajido, Araromi Oke, Badore, Ebute Lekki, Egan, Ibese, Igbogbele, Ipare, Iyagbe, Kesumetta, Makun and Olute. Deforestation and mangrove degradation was a major problem being faced in Ibasa and pollution was indicated severe in Badore, Ibereko, Igbede, Ilase, Wasere and Yaye. Soil fertility affects majorly farmers in Araromi Obu, Ikaare, Isagira, Kweme, Okun Ibese, Olotu/Eruna, Ropoji, while sand mining had high response rate in seven communities which are Ago Iba, Aradagun, Araromi, Ganyingbo, Igbokoda, Isekun and Ode-Mahin. Mixed issues (in form of flooding and sand mining) also present themselves in high rate in communities such as Ebaa, Gbabijo, Ilepete and Ugbonla.

In terms of the various ecological zones the strand ecological zone experiences more of flooding, then water hyacinth, pollution and sand mining. Deltaic swamp ecological zone had more of flooding followed by pollution, water hyacinth and then coastal erosion. What obtains in the mangrove ecological zone was different as sand dredging was indicated to the dominant, followed by flooding and then pollution. Flooding was ranked as the most severe environmental degradation across the three ecological zones and there is a spatial variation in environmental degradation.

Rigorous community efforts are needed to provide leadership and modalities for the management of environmental challenges in coastal communities. More significantly, modern equipment that can enhance coastal socio-economic activities will reduce the volumes of environmental challenges in Nigeria be provided by the government at all levels. In this regard, projects and innovative measures for environmental protections should be provided.

\section{SUGGESTED AREAS FOR FURTHER STUDY}

For further research, the aspect of temporal dimensions of environmental degradation in the coastal areas of south west, Nigeria should be examined, and in relation to the ecological zones. This will make a comparative analysis of how the environment has been over the years possible. Thus, deductions can be made on whether the environment has been degenerating or improving over time. Also, this will make known how global warming has impacted the environment over time.

\section{REFERENCES}

Ademiluyi, I. L. and Solanke, M. O. (2004). Towards effective environmental management for sustainable development in Nigeria. Economic and social issues in population, environment and sustainable development in Nigeria, 157164.

Awosika, L. F., Osuntogun, N. C., Oyewo, E. O. and Awobamise A. (2001). Development and Protection of the Coastal and Marine Environment in Sub Sahara Africa: Report of the Nigeria Integrated Problem Analysis.

Danjuma, M. N., Mohammed, S. and Daura, U. S. (2014). Mitigation Strategies to Environmental Degradation in Nigeria. Journal of Environment and Earth Science, 4(21).

Dimuna, K. O. and Dimuna, J. E. (2007). Environmental pollution and sustainable development in Niger Delta Region of Nigeria. Confluence Journal of Environmental Studies, 2(1), 28-40.

EEA. (1999). Environmental indicators: Typology and overview. Technical Report, 25, EEA. Copenhagen, Denmark.

Global International Waters Assessment (GIWA). (2018). GIWA in brief. Available at: https://www.giwa.net (Accessed 16 July 2018)

Igben, J. L. (2012). Environmental dynamics and labour input of the rural population in Delta State, Nigeria. Journal of Environment Management and Safety, 3(5), 15-26.

Jesinghaus, J. (1998). A European system of environmental pressure indices: First volume of the environmental pressure indices handbook: The indicators. Available at: http://esl.jrc.it/envind/theory/hand (Accessed 23 August 2016).

Jimoh, H. I. (2000). Man-environment interaction. In H. I. Jimoh and I. P. Ifabiyi (eds.), Contemporary issues in environmental studies (pp 20-27). Ilorin: Haytee Press and Publishing Co. Ltd.

Jimoh, I. H. (2006). Pattern of environmental degradation and development efforts, in H.A. Saliu, A.A. Ogunsanya, J. O. Olujide and J. O. Olaniyi (eds.), Democracy and development in Nigeria: Economic and environmental issues Vol 2. Lagos: Concept Publications.

Kristensen, P. (2004). The DPSIR Framework. Paper presented at the workshop on a comprehensive/detailed assessment of the vulnerability of water resources to environmental change in Africa using river basin approach. UNEP Headquarters, Nairobi, Kenya, 27-29 September 2004. 
Kukreja R. (2015). Conserve Energy Future. Available at: http://www.conserve-energy-future.com/causes-andeffects-of-environmental-degradation.php

OECD. (2001). Glossary of statistical terms.

Ofomata, G. E. K. and Phil-Eze, P. O. (2007). Introduction. In G. E. K. Ofomata and P. O. Phil-Eze (Eds.), Geographical perspectives on environmental problemenvironmental degradations and management in Nigeria (pp. 1-10). Enugu: Jamoe Publishers.

Okebukola, P. (2001). Our Environment Our Destiny 2nd Distinguished Lectures Series AOCOED. On 1st March, 2001, Otto/Ijanikin Lagos.

Okosodo, L. A. and Omonzejie, P. I. (2004). Environmental problemEnvironmental degradations and sustainable development in Nigeria. In O. A. Ibitoye (Ed.), Scientific and environmental issues in population, environment and sustainable development (pp 33-37). Lagos: Graams Prints.

Oladeji, J. O. (2007). Effect of land degradation on income generating activities of farmers in Imo State, Nigeria. Journal of Economics and Rural Development, 16(1), 93-106.

Onumadu, F. N., Popoola, L. and Akinsorotan, A. O. (2001, September). Environmental forestry extension: the missing links. In Proc. of the 27th Annu. Conf. of FAN beld in Abuja, FCT between 17th and 21st of (pp. 290-298).

Petters, S. W. (1995). Natural and man-made hazards. In S. W. Peters et al. (Eds.) Environmental education. (pp. 134-151) Lagos: Nigerian Conservation Foundation.

Rigby, D., Howlett, D. and Woodhouse, P. (2000). Sustainability Indicators for Natural Resource Management and Policy Working Paper 1. A review of indicators of agricultural and rural livelihood sustainability. IDPM, University of Manchester, Manchester.

Twumasi Y. A. (2006). GIS and Remote Sensing Applications in the Assessment of Change within a Coastal Environment in the Niger Delta Region of Nigeria.

Uche, S. C. (1995). Education and sustainable development. In M. B. Lawal et al. (eds.). Education for sustainable development (pp 1-21). Lagos: Nigerian Conservation Foundation.

UNISDR. (2007). United Nations Research Institute for Social Development.

Weller, K. (2005). Human Modification of the Nigerian Environment the University of Northern Iowa Geographic Alliance of Iowa, Cedar Falls Iowa background Information and study Areas on Nigeria.

Xue, H. J. (2006). Spatial-temporal dynamic change of land resource degradation in China. 